\title{
The Protection of Cultural Heritage vs. the Right to Private Property: The Extraordinary Case of the Portrait of Dr. Gachet by Vincent van Gogh
}

\author{
Kamil Zeidler - Aleksandra Guss
}

Prof. dr hab. Kamil Zeidler

University of Gdańsk, Faculty of Law and Administration

Department of Theory and Philosophy of the State and Law

Corresponding adress: ul. Jana Bażyńskiego 6, 80-952 Gdańsk

e-mail: kamil.zeidler@ug.edu.pl

ORCID: 0000-0002-8396-3608

Aleksandra Guss, MA

University of Gdańsk, Faculty of Law and Administration

Department of Theory and Philosophy of the State and Law

e-mail: aleksandra.guss@phdstud.ug.edu.pl

ORCID: 0000-0002-4157-6853

Muzeológia a kultúrne dedičstvo, 2021, 9:4:57-68

DOI: $10.46284 / \mathrm{mkd} .2021 .9 .4 .4$

The Protection of Cultural Heritage vs, the Right to Private Property: The Extraordinary Case of the Portrait of Dr. Gachet by Vincent van Gogh

In 1890, Vincent van Gogh moved from Paris to Auvers-sur-Oise, where he met Dr. Paul-Ferdinand Gachet, who agreed to host and take care of the painter, especially regarding his mental health. However, he did not manage to save the artist, who committed suicide the same year. His hopeless mental health was seen in the famous portrait of Dr. Gachet, which radiated a distinct melancholy and sadness. The Portrait of Dr. Gachet was bought for $\$ 82.5$ million by a Japanese millionaire and art collector, Ryoei Saito, who said that after his death it was to be burned along with his corpse. It raised loud objections in the art world, which recognised the common good and the legacy of our cultural heritage in the painting. This case is a classic example of a dispute between the ideals of liberalism and communitarianism and is seen as a hard case in law. The aim of the article is to present the history of The Portrait of Dr. Gachet and its place in the dispute between liberalism and communitarianism (in the context of cultural heritage law), which in turn means that this case can be seen as a hard case.

Keywords: Cultural Heritage Law, Art Law, Hard Cases, Liberalism vs. Communitarianism, Philosophy of Law

\section{Introduction}

Vincent van Gogh met Dr. Paul-Ferdinand Gachet in 1890 when he moved to Auvers-surOise to be closer to his brother, Theo. The doctor then agreed to host and take care of the painter, especially regarding his mental health. However, he did not manage to save the artist, who committed suicide the same year. The stay in Auvers-sur-Oise resulted in many paintings, including a famous portrait of Dr. Gachet, which was painted in two versions. Both were very similar and they radiated a distinct melancholy and sadness, which could reflect van Gogh's hopeless mental health.

Not appreciated during his lifetime, van Gogh gained fame after his death and nowadays his paintings on the international art market, if they appear, reach dizzying, even record-breaking prices at auctions. This was also the case with The Portrait of Dr. Gachet, which was sold 
K. Zeidler - A. Guss: The Protection of Cultural Heritage vs. the Right to Private Property...

for $\$ 82.5$ million. The painting was bought by a Japanese millionaire and art collector Ryoei Saito, who said that after his death it was to be burned along with his corpse. It raised loud objections in the art world, which recognised the common good and the legacy of our culture in the painting. There was no doubt that it was a part of cultural heritage, which should be protected by law. This case is a classic example of a dispute between the ideals of liberalism and communitarianism and is seen as a hard case in law. The aim of the article is to present the history of The Portrait of Dr. Gachet and its place in the dispute between liberalism and communitarianism (in the context of cultural heritage law), which in turn means that this case can be seen as a hard case. Secondly, the article contains questions that a potential judge wishing to solve a case should answer by weighing values and principles.

\section{The Portrait of Dr Gachet by Vincent van Gogh}

In 1890, Vincent van Gogh moved from Paris to Auvers-sur-Oise, a town located an hour by train from Paris. While he was living there, Dr. Paul-Ferdinand Gachet, who was a friend of many Impressionist painters (including Cézanne and Pissarro), as well as a patron of the arts and an amateur painter, agreed to host and take care of Van Gogh. In the same year, on 29 July, the painter, tormented by anxiety of spirit and deepening depression, took his own life. Dr. Gachet, as a psychiatrist, tried many times to diagnose the artist's mental illness; however, he was unable to prevent him from committing suicide.

During his stay in Auvers-sur-Oise, Vincent van Gogh painted over 80 canvases (which is on average more than one a day), in particular picturesque houses, hills, and wheat fields (e.g., Champ de blé aux corbeaux, 1890). He also painted a portrait of Dr. Paul-Ferdinand Gachetin two versions. ${ }^{1}$

Both paintings show a distinct melancholy. One may be tempted to say that the painting reflects two poor mental states - the painter himself, and, as might be suspected, also Dr. Gachet. As van Gogh wrote about the doctor's face, expressing sadness and grief: "he certainly seems to be suffering as seriously as I", and "he is sicker than I am". ${ }^{2}$ Dr. Gachet was portrayed in a head-in-hand pose, with a sad gaze directed into the distance and with a face that Van Gogh described as a "heartbroken expression of our time". "The depressive nature of the painting is additionally emphasised by the gloomy colours used. The dark blue coat of the doctor and the blue undulating hills in the background accentuate his tired features, pale face, and the pain of his blue eyes. Colour undoubtedly plays a symbolic role here as a metaphor for sadness (according to, for example, the saying "to feel blue"). Moreover, many people see a similarity between Portrait of Dr. Gachet, and a Self-portrait of the painter in the expressions of the faces-as if van Gogh wanted to transfer "himself" to a portrait of a doctor. Therefore, this picture is not treated only as a depiction of a sad man, but is seen as a complex psychological case that raises many questions and prompts the viewer to seek answers. The emotions expressed in the

\footnotetext{
${ }^{1} 1890$, oil on canvas, ca. $67 \times 56 \mathrm{~cm}$; the story concerns the first of them, although it should be mentioned that the second version of the portrait — considered to be weaker and even raising doubts as to its originality - is in the collection of the Museum d'Orsay in Paris; see also: SALTZMAN, Cynthia. Portrait of Dr. Gachet: The Story of a van Gogh Masterpiece: Money, Politics, Collectors, Greed, and Loss. New York: Viking, 1998; see also: HENLEY Jon. The Remarkable Dr Gachet. In: The Guardian, 28 January 1999, accessed 31 October 2020, https:/ /www.theguardian.com/ artanddesign $/ 1999 /$ jan $/ 28 /$ arttheft.art.

${ }^{2}$ ARONSON, Jeffrey K. and RAMACHANDRAN, Manoj. The diagnosis of art: melancholy and the Portrait of Dr Gachet. In: Journal of the Royal Society of Medicine, 2006, 99(7), p. 373.

${ }^{3}$ WALLACE, Robert. The World of Van Gogh. New York: Time-Life Books 1969, pp. 174-75.
} 
painting and the mystery which it hides within itself undoubtedly contributed to its uniqueness, and thus aroused interest in the art market after the artist's death.

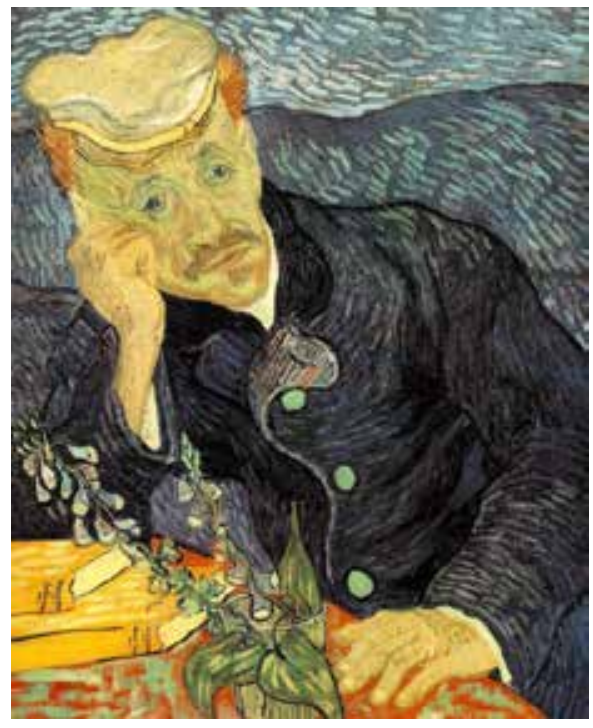

Fig. 1: The Portrait of Dr Gachet by Vincent van Gogh, 1890, bttps://pl.wikipedia.org/ wiki/Portret_doktora_Gacheta\#/medial Plik:Portrait_of_Dr._Gachet.jpg

During his lifetime, Vincent van Gogh sold only one painting - The Red Vineyard (today at the Pushkin Museum of Fine Arts in Moscow). ${ }^{4}$ However, after his death, his fame began to grow rapidly, and nowadays on the international art market, Vincent van Gogh's paintings, if they appear, reach amazing, record-breaking prices at auctions. The most famous of over eight hundred works painted by the artist ${ }^{5}$ have been a constant and important component of the best museum collections in the world for decades. These are the pride of those museums that can mostly be classified-colloquially speaking-in the champions' league of the world's museums.

At an auction in Christie's in New York, one of the two largest auction houses in the world (the other is Sotheby's), on 15 May 1990, Van Gogh's painting Portrait of Dr. Gachet was sold for $\$ 82.5$ million. It was at that time an auction record that was subsequently not broken for fourteen consecutive years. To this day, is one of the most expensive works of art ever sold at auction and the most expensive painting by Van Gogh. The famous painting was bought by the Japanese millionaire and art collector Ryoei Saito. ${ }^{6}$ The new owner liked the work so much that he announced that after his death it was to be burnt together with his corpse. It caused a veritable storm and loud opposition in the art world. However, when the owner died in 1996, there was no further information disclosed about the painting and it has not been seen in public since its purchase in $1990 .^{7}$ We still do not know what happened to the painting, and although eventually declarations were made that the painting was not burned, and that Ryoei Saito only joked when describing his love for art in this way, it is not certain whether the owner's last will was fulfilled or not. Although some theories about its fate appear in the press, it is a fact that

\footnotetext{
${ }^{4}$ CHILVERS, Ian and OSBORNE, Harold. The Oxford Dictionary of Art. Oxford: Oxford University Press, 2004, p. 281.

${ }^{5}$ Vincent van Gogh discovered a creative fascination with painting quite late in life, but as it happened, he worked extremely intensively; E.H. Gombrich wrote about him: "his career as a painter lasted less than 10 years. All the paintings thanks to which he became famous were created within three years marked by attacks of disease and despair”. GOMBRICH, Ernst Hans. O sqtuce. Warsaw: Wydawnictwo Arkady, 2009, pp. 545-546.

${ }^{6}$ Ryoei Saito bought another painting two days later, this time at Sotheby's in New York: Pierre-Auguste Renoir's Au moulin de la galette from 1877 for \$ 78 million; see: MCCARTHY, T., Christie's New York auction, Tuesday, 15 May 1990. For sale: Van Gogh's Portrait of Dr Gachet... In: The Independent, 16 November 1993, accessed 31 October 2020, https:/ / www.independent.co.uk/life-style/the-last-of-the-big-spender-ryoei-saito-last-week-under-arrestand-in-deep-trouble-a-far-cry-from-1504552.html.

${ }^{7}$ CHARNEY, Nancy. Lost Art: When Works Disappear into Private Collections. In: The Art Newspaper, 8 November 2018, accessed 31 October 2020, https://www.theartnewspaper.com/feature/lost-art-when-works-disappear-intoprivate-collections.
} 
K. Zeidler - A. Guss: The Protection of Cultural Heritage vs. the Right to Private Property...

the painting has not been shown to the public for the last thirty years. ${ }^{8}$

The above can be supplemented with two observations. First, the Japanese, whose national traits include sensitivity to beauty, highly value the achievements of European art; second, European art from that period, at the end of the nineteenth and the beginning of the twentieth century, drew inspiration from Japanese art in handfuls, especially from woodcuts. This fascination by no means excluded van Gogh and it had a visible impact on his work. ${ }^{9}$ So the Japanese millionaire, although this is of course speculation, could find in the artist's work a resonance that was culturally close to him.

The mysterious fate of the painting, and the testator's will in particular, raise many doubts not only of a legal, but also social and moral nature. In fact, in the case of the portrait of Dr. Gachet, legal norms collide with the norms of other systems, creating the so-called hard case in law.

\section{Hard Cases in Law}

Although the problem of hard cases was raised by many other philosophers of law, including John Austin, in his concept of positivism, the theory of this issue emerged and gained fame, above all, in the course of a debate between Herbert L.A. Hart and Ronald Dworkin. ${ }^{10}$ The concept of hard cases is associated primarily with the latter-it was Dworkin who published a comprehensive essay, Hard Cases ${ }^{11}$, in the Harvard Law Review in 1975, which referred to his 1971 lecture at Oxford on the basis of the famous case of Riggs v. Palmer. ${ }^{12}$

Often the main axis of the Hart-Dworkin dispute is identified with the question of whether a law is just a set of "zero-one" rules, or whether it also includes rules that are graded and used to resolve the hard cases. Hart believed that a hard case arises when the rules of law do not themselves lead to the resolution of a legal problem, and its solution requires appeal to a non-legal system, thanks to the open texture concepts. This was connected with breaking the connection between the rule and the decision and relying on judicial discretion, going beyond the legal system (Hart also defends the idea that a judge's decision made in a hard case is a

\footnotetext{
${ }^{8}$ See: BAILEY, Martin. Where is the Portrait of Dr Gachet? The Mysterious Disappearance of Van Gogh's Most Expensive Painting. In: The Art Newspaper, 15 November, accessed 31 October 2020, https:/ /www.theartnewspaper. $\mathrm{com} / \mathrm{blog} /$ where-is-van-gogh-s-portrait-of-dr-gachet; as we read in this article, the reason that the painting-if it still exists - is not publicly displayed and its possible owner remains in the shadows is the potential restitution claim related to the confiscation of the van Gogh collection due to the work having been looted by the Nazis in the 1930s. ${ }^{9}$ See: GOMBRICH, O squtuce, p. 546.

${ }^{10}$ See: SHAPIRO, Scott J. The "Hart-Dworkin” Debate: A Short Guide for the Perplexed. In: Ronald Dworkin, ed. RIPSTEIN, Arthur. Cambridge: Cambridge University Press, 2007, pp. 22-55; LEITER, Brian. Beyond the Hart/ Dworkin Debate: The Methodology Problem in Jurisprudence. In: The American Journal of Jurisprudence, 2003, 48(1), pp. $17-51$.

${ }^{11}$ DWORKIN, Ronald. Hard Cases. In: Harvard Law Review, 1975, 88(6), pp. 1057-1109.

${ }^{12}$ Riggs v. Palmer, Court of Appeals of New York, 115 NY 506 (1889); Dworkin describes the essence of the case as follows: "In 1889 a New York court, in the famous case of Riggs v. Palmer had to decide whether an heir named in the will of his grandfather could inherit under that will, even though he had murdered his grandfather to do so. The court began its reasoning with this admission: 'It is quite true that statutes regulating the making, proof and effect of wills, and the devolution of property, if literally construed, and if their force and effect can in no way and under no circumstances be controlled or modified, give this property to the murderer.' But the court continued to note 'that all laws as well as all contracts may be controlled in their operation and effect by general, fundamental maxims of the common law. No one shall be permitted to profit by his own fraud, or to take advantage of his own wrong, or to found any claim upon his own iniquity, or to acquire property by his own crime.' The murderer did not receive his inheritance"; see: DWORKIN, Ronald. Taking Rights Seriously. Cambridge: Harvard University Press, 1977.
} 
law-making decision, because the standard of a correct judicial decision is determined by the semantic scope of a rule containing open-texture expressions). ${ }^{13}$

Dworkin, in turn, pointed out that in the legal system there are also norms that are principles and policies. They differ from the rules in that they are not exhausted in the "zero-one" calculus. Thus, the judge weighs certain reasons without going beyond the legal system; on the contrary, a solution should be sought within the system on the basis of rules and policies. In accordance with the integral philosophy, Dworkin indicates that the judge should remain within the legal system and refer to the legal principles, thus bringing the standards out of the legal system. ${ }^{14}$

It is worth mentioning, however, that Hart pointed out in the Postscriptum that he treats the concept of a rule broadly enough to also include principles, ${ }^{15}$ which in some way changes the further form of the dispute that continues today through the continuators of these two philosophers.

However, the debate significantly contributed to the development of the hard case concept, but it is emphasised that the approach to hard cases resulting from the dispute is narrow, and perhaps even too narrow, as it is limited only to the process of applying the law and possibly its interpretation. The legal system is not limited to these two phenomena and looking broadly, it can be seen that hard cases can occur on all five levels of law: the law-making process, the application of law, the interpretation of law, the validity of law, and compliance with the law ${ }^{16}$. This means that hard cases are not only within the domain of the judge, seeking a solution in a specific case where there is no clear legal rule, as it was presented by Hart. This may also apply to, for example, the legislator who decides to regulate or to refrain from regulating a specific sphere of social relations. ${ }^{17}$ Therefore, a hard case does not necessarily have to do with the law in force and sometimes arises in the context of a lack of regulation, giving rise to the question of whether to regulate the issue or not.

It should also be noted that Dworkin emphasized that in hard cases there is only one right answer, but in fact, paradoxically, such a situation would result in an easy case - because it would not be necessary to conduct the entire argumentative discourse. This means that the determining factor for a hard case in law is the multiplicity of possible solutions to a given case and many correct findings. ${ }^{18} \mathrm{~A}$ hard case occurs where law collides with itself or with other normative systems or values, for example, with morality (most often), religion, customs, politics, economy, etc. ${ }^{19}$ That is why the solution of a hard case does not proceed clearly from the legal rules applied, and most frequently in such a situation it is necessary to appeal to norms other than legal ones and to assessments and evaluations-this appears in the case of a conflict of legal principles (internal conflict) or of the flagrant conflict of the law and another

\footnotetext{
${ }^{13}$ ZAJADLO, Jerzy. Co to są hard cases? In: Fascynujace ścieżki filozofii prawa, ZAJADLO, Jerzy (ed.), Warsaw: LexisNexis, 2008, pp. 7-19.

${ }^{14}$ Ibidem.

${ }^{15}$ See: HART, Herbert. Postscript. In: The Concept of Law, 2nd ed., BULLOCH Penelope A. and RAZ, Joseph (eds.). Oxford: Clarendon Press, 1994.

${ }^{16}$ ZAJADLO, Co to są hard cases..., pp. 9-10.

${ }^{17}$ See ZEIDLER, Kamil. Czy w prawie prywatnym występują trudne przypadki? In: Państwo i Prawo, 2018, 9, pp. 75-76.

${ }^{18}$ ZEIDLER, Kamil. Restitution of Cultural Property. Hard Case, Theory of Argumentation, Philosophy of Law. Gdańsk-Warsaw: Gdansk University Press, 2016, p. 19.

${ }^{19}$ For example, David Lyons sees a hard case in the collision of law and moral decisions. See: LYONS, David. Ethics and the Rule of Law. Cambridge: Cambridge University Press, 1984; KRAMER, Matthew H. Where Law and Morality Meet. Oxford: Oxford University Press, 2004.
} 
important and recognised normative order (external conflict). ${ }^{20}$

The lack of one right answer results in the necessity to constantly weigh rules and values in order to give precedence to one of them in a given case. Occasionally it is the subject of the dispute that makes the case a hard case. This is the situation with cultural property, which is particularly visible in the case of Dr. Gachet's portrait, where two interests collide- the interest of the individual, relating to property rights and fulfillment of the testator's will; and public interest, relating to the possibility of limitation of property rights in order to protect common goods, which are in this case a part of cultural heritage.

\section{The Case of Dr. Gachet's Portrait as a Hard Case}

As can be seen from the above, we deal with a hard case in law, especially when, in a decisionmaking situation, it is necessary to weigh the values so as to give one of them priority over the other. The case presented here is related to the problem of a dispute between individual rights and the general interest. On the one hand, we have the right of ownership at stake, here the owner of a unique work of art, and on the other hand, this work of art is a common good whose protection is in the public interest. This is because one of the main assumptions of the cultural heritage law is based on the fact that it consists of items of exceptional value (historical, artistic, scientific, etc.) that justify their protection. This protection goes beyond the ordinary protection of a thing in civil or even criminal law, which results from the right to property. This is protection of a public-law nature, using mainly instruments of public international law, very often constitutional law, administrative law, and finally also criminal law. The justification for such extensive protection of individual components of cultural heritage-cultural property, monuments, works of art, etc.-is the goal of preserving them in the best possible condition for future generations. The keynote of Derek Gillman's book The Idea of Cultural Heritage is that, on the one hand, works of art belong to a specific owner, whether it is a public entity, such as a museum or a private collector; on the other hand, however, they belong, as an element of cultural heritage and the common good, to all mankind. ${ }^{21}$ And here arises the question about the possibility of universal access to them and their use by more people than just the owner of a given work of art.

It is worth recalling the words of Hippocrates, which were later repeated in translation by Seneca-ars longa vita brevis. So life is fleeting, and art "lives" long. In other words, "eternal life is the natural destiny of art". ${ }^{22}$ A special feature of monuments is that they were created in a more or less distant past, they were created by the hands of an often brilliant, exceptional artist, and often survived for many generations. However, there is no chance that once lost or destroyed, they will be restored to us, because time will not go backwards and the creators will not be revived. So they are sanctified by successive generations, as memorials to people who have passed away and were only "episodes in the life of things"; and to past historical events that these cultural goods fortunately survived. Thanks to this, they can serve us today. However, at the same time we, living today, are burdened with the obligation to care for them and to pass them on to the next generations in the best possible condition. And, first and foremost, it is justified to treat cultural property as a common good that should be protected independently, sometimes even against the will of its owner or holder.

\footnotetext{
${ }^{20}$ ZEIDLER, Restitution of Cultural... pp. 19-20.

${ }^{21}$ See: GILLMAN, Derek. The Idea of Cultural Heritage. Cambridge-New York: Cambridge University Press, 2011.

${ }^{22}$ SCHWARTZ, Gary. Ars Moriendi: The Morality of Art. In: Art in America, 1996, 11, pp. 72-75.
} 
The right to property, as the broadest subjective right, contains several elements, and traditionally consists of: ius possidendi (the right to own things), ius utendi (the right to use things), ius fruendi (the right to receive benefits from things), ius disponendi (the right to dispose of a thing), and ius abutendi, that is, the right to use up or even destroy things. However, today the right to property is subject to various restrictions. In democratic states, these rights are provided for by law and may not be arbitrary in any way, and in particular may not infringe the essence of the right to property.

In the facts described here, we are dealing with a dispute that arose on the line between two concepts: property rights versus protection of the common interest. The owner legally acquired van Gogh's painting, paying a record price for it at the auction. He could therefore dispose of the subject of his property rights. But is it certain that these rights should also include the right to destroy the work, or, perhaps due to its uniqueness and special values, should the ownership right be limited? The mere fact that someone is rich enough to afford to buy works of art of the highest value should in no way allow him to destroy the work, especially when we are dealing with the most valuable and preserved works of art. Moreover, the fact of the exceptional value of such works implies special obligations on the part of the owner-taking care of them, their proper and safe storage, and, if necessary, conservation. But is it really so? The problem described here is quite new, because previously, for centuries, it was the commissioner who decided what would happen to the work made for him by the artist, and in this respect he had full ownership rights.

We should not reduce the considerations here to seeking answers on the basis of a specific law in force in a particular country, be it the United States, Japan, or any other. In many countries, in particular those belonging to the broadly understood European legal culture, we find regulations on the protection of cultural heritage, which directly exclude the possibility of destroying an item considered a monument. However, that does not make the matter at hand an easy case. It remains hard, because this constantly occurring dispute of values-between the variously understood interests of an individual and the common good-is independent of any attempt to regulate it by law. Similarly to the normative-legal regulation of other hard cases, such as the admissibility of the death penalty, abortion, euthanasia, and others, it does not make them an easy case. Moreover, an improper attempt to regulate a given issue may turn it into a hard case in law, or may make a hard case in law even harder. The same will be true of the problem of the value dispute analysed here and the related questions about the permissible scope of interference with the right to property in contemporary democratic states of law.

The matter discussed here can be even more general. The most pressing dispute of modern times, not only in legal sciences, is that known as liberalism versus communitarianism. It also concerns the law of protection of cultural heritage. ${ }^{23}$ In the aforementioned book, Derek Gilliam writes that one of the two most important debates on cultural heritage in recent decades has been one that fits directly into the conflict between liberalism and communitarianism. ${ }^{24}$ Representatives of both positions not only present various alternatives and compromise proposals, but also propose specific political, economic, and social solutions, and prefer different positions in the field of social morality. They also treat the law and its role differently, as well as the meaning and functions of these in contemporary societies. While much has

\footnotetext{
${ }^{23}$ See: ZEIDLER, Kamil and LA_GIEWSKA, Magdalena. Liberalism Versus Communitarianism in Cultural Heritage Law. In: International Journal for the Semiotics of Law - Revue internationale de Sémiotique juridique, 43(1), 2020, pp. 657-668. ${ }^{24}$ GILLMAN, The Idea of Cultural Heritage..., pp. 1-2.
} 
K. Zeidler - A. Guss: The Protection of Cultural Heritage vs. the Right to Private Property...

already been written about both liberalism and communitarianism and the ongoing dispute, one can still only guess at their different positions with regard to cultural heritage and its protection. Therefore, it is important to ask about the position of representatives-of liberal and communitarian thought, respectively-on the issue of the protection of cultural heritage in general, and the admissibility and scope of interference with property rights in particular; and of course when considering the ownership of cultural property. The problem presented here is by no means new. The same question about the limitation of the owner's right in a case when the object of his right is a cultural property, although framed in a slightly different way, was posed by Joseph L. Sax in Playing Darts with a Rembrandt: Public and Private Rights in Cultural Treasures. ${ }^{25}$

Ultimately, however, it is necessary to do justice to the owners of cultural property, emphasising that it is they who most often make efforts and care for the protection of their monuments and works of art. Thus, they are the most effective "component" of the system for the protection of cultural heritage in general. Ideas that this role could be taken over by the state did not work, as many examples from the second half of the twentieth century in communist and socialist countries show. Therefore, it is important to try to reconcile potentially conflicting interests wherever and whenever possible. However, in those cases where it occurs, we are most often dealing with hard cases in law.

\section{Weighing Values in Search of a Solution}

In light of the facts cited here and the problem posed, consisting in a dispute of interests, goods, and values, one can put oneself in the role of a judge who is to decide on the performance of or refusal to comply with the deceased's last will. Therefore, let us formulate the three main questions that this judge will have to deal with in order to pass judgment: Firstly, can the ownership of a work of art be unlimited? Secondly, is recognising things, in this case works of art, as the common good a justification for interference with property rights? And if so, what are the limits of this interference and is it possible to deprive the owner of ownership for the sake of protection? Regarding this point, one must remember the problem of compensation in such cases. And thirdly, could Ryoei Saito expect his will for a favourite work of art to be executed?

The right to property comes from ancient times, and is considered to be a natural or fundamental human right. ${ }^{26}$ Concepts of natural law emphasise that human and civil liberties and rights, including the right to private property, have a legal and natural character, and therefore are not established or granted by state bodies, but are only declared and guaranteed by them in the form of positive law. Hugo Grotius treated property as one of the fundamental principles of the whole law of nature, which was a system of norms that were unchanging, permanent, and independent of the will of any legislator, ${ }^{27}$ and thus perceived that property was unfettered. John Locke, on the other hand, applied the concept of appropriation to goods of nature, animals, and land-with his law of nature forbidding such appropriation that could lead to harm to other people. ${ }^{28}$ Property was perceived differently by Max Weber, giving it an

\footnotetext{
${ }^{25}$ See: SAX, Joseph L. Playing Darts with a Rembrandt: Public and Private Rights in Cultural Treasures. Ann Arbor: The University of Michigan Press, 2004.

${ }^{26}$ See: MACK, Eric. The natural right of property. In: Social Philosophy and Policy, 27(1), 2010, pp. 53-78.

${ }^{27}$ See: NEFF, Stephen C. (ed). Hugo Grotius on the Law of War and Peace. Cambridge: Cambridge University Press: 2013, pp. 13-35.

${ }^{28}$ See LOCKE, John. Second Treatise of Government. Indianapolis: Hackett Publishing, 1980.
} 
absolute character, independent of the will and interests of non-owners and keeping it also in the modern social state, introducing numerous restrictions on ownership activities. ${ }^{29}$

The general concept of ownership includes the owner's right to treat things in any way. Currently, the right to property is the systemic basis and constitutional principle of all modern democratic states. The legal practice of democratic states determines in what circumstances property is individual or collective property, and whether and in what form the sovereignty over a thing may be limited. It should be emphasised that the interference with this right, and in particular its limitation, cannot be arbitrary and cannot be left out of any control. As mentioned earlier, most often the right to property will be limited by the aforementioned "common good" or "public interest". It should be noted, however, that the conflict of the interests of the individual with the interests of the community will not always justify the interference with the right to property, and even if it does, it cannot be arbitrary and not subject to any control. ${ }^{30}$

Ownership is not only a legal category, but an interdisciplinary issue that covers the field of economics and social sciences, including, primarily, sociology and psychology. The latter treats property as part of human nature. A human strives for possession, and this is often his main form of motivation to work, especially in recent years-we work harder to have more, which has given rise to a negative and growing phenomenon of consumerism. Ownership, therefore, has an overwhelming impact on almost every sphere of life, it gives people the motivation to action, and at the same time is a kind of promise of their success in life, as well as strengthening social positions. ${ }^{31}$ Hence, possession of works of art is associated with a certain prestige. This is the more so because as well as the entire process that accompanies the purchase of works of art, e.g., during an auction, such a work is characterised by its rarity, usually existing only as one copy, and its high economic value. Moreover, ownership is associated with the creation of an emotional bond between the owner and the item. This is particularly visible in the ownership of works of art-the reasons for buying a given work are very often the emotions it arouses or its meaning. In the case of Van Gogh's painting, such a bond must have been strong, since Ryoei Saito wanted the work to burn with his corpse, that is, to be with him until the last moment of his physical existence. It all makes the possession of a work of art different from the possession of an ordinary thing. However, it should be considered whether the work's high economic value and the emotional attitude of the owner towards the work may exceed its priceless cultural value, manifesting in its meaning for society.

As we already know, the most important prerequisite for interference with the right to property is the protection of the common good. The Latin root of "common", communis, is the same as the root of "community"; it evokes "general", "free" and "public" all at the same time. Alternatively, the common good can be called "public interest" or "public goods", as the main subject of all three concepts are goods that serve all members of the community and its institutions. It is a normative concept that comes from ancient times, as is the case with the concept of property.

\footnotetext{
${ }^{29}$ See DUSZA, Karl. Max Weber's Conception of the State. In: International Journal of Politics, Culture, and Society, 3(1), 1989, pp. 71-105.

${ }^{30}$ ZEILDER, Kamil. Ograniczenie prawa własności w świetle sporu liberalizmu z komunitaryzmem. In: Gdańskie Studia Prawnicze, 36, 2016, p. 541.

${ }^{31}$ ZALEWSKI, Zbigniew. Psychologia wtasności i prywatności. Warsaw: Wydawnictwo Żak 2003, pp. 15-112. See also KLINE Linus W. and FRANCE, C. J. The Psychology of Ownership. In: The Pedagogical Seminary, 6(4), 1899, pp. $421-470$.
} 
The fact that cultural heritage is perceived as a common good can be inferred from the UNESCO Convention Concerning the Protection of the World Cultural and Natural Heritage, adopted in Paris on 16 November 1972. This is evidenced by the emphasis that the safeguarding of cultural heritage, this unique and irreplaceable property, is important to all the peoples of the world, whichever people to whom it may belong. Thus, the Convention commits the international community as a whole to participate in the protection of the cultural heritage, which is of outstanding interest and therefore needs to be preserved as part of the world heritage of mankind as a whole. Article 1 provides a catalogue of goods that make up the cultural heritage, among which are mentioned: architectural works, works of monumental sculpture and painting, elements or structures of an archaeological nature, inscriptions, cave dwellings and combinations of features, all of which are of outstanding universal value from the point of view of history, art, or science.

Francesco Francioni indicates that: "cultural property today can be seen as the object of individual rights, property rights, but also as 'communal property' or public patrimony, which is essential to the sentiment of belonging to a collective social body and to the transmission of this sentiment to future generations. ${ }^{32}$ Heritage is protected not as a thing with "its own intrinsic value - aesthetic, historical, archaeological-but rather because of its association with a social structure of a cultural community which sees the safeguarding of its living culture as part of its human rights claim to maintain and develop its identity as a social body beyond the biological life of its members." 33

So should The Portrait of Dr. Gachet be considered as such a good, and consequently as a common good? It cannot be denied that Vincent van Gogh is seen as one of the greatest revolutionaries in the history of painting, who, unaware of his genius, changed the fate of art. $^{34}$ The unique style of his works, manifested in the technique (quick, short, and rhythmic brush strokes) and the color palette (full of shades of yellow and blue), brought him enormous fame after his death. However, these are not the only factors that make Van Gogh's works rare, because the interpretation of his paintings is accompanied by the history of the artist's life, and his mental illness, loneliness, and sadness. The Portrait of Dr. Gachet is one of the last paintings by Van Gogh, and the mystery and sadness emanating from the painting reflects the artist's mental state just before his suicide attempt, perhaps even being its foreshadowing. Hence, Van Gogh's paintings cannot be denied an artistic as well as a historical value, and thus they constitute a cultural heritage that is a common good. It seems that the importance attached to the protection of cultural heritage as a common good, which is emphasised by the international community and is reflected in many acts of international and national law, justifies the infringement of property right to a work of art, which is a component of this heritage, in particular if this is to protect against its destruction or damage. ${ }^{35}$

As emphasised earlier, a property right consists of several elements; it includes ius possidendi, ius utendi, ius fruendi, and ius disponendi. Among the rights of the owner we distinguish the right to dispose of the thing, including its destruction. In the case of a work of art characterized by a specific value, this part of the owner's right is excluded. ${ }^{36}$ For if a work ofart-even though

\footnotetext{
${ }^{32}$ FRANCIONI, Francesco. Public and Private in the International Protection of Global Cultural Goods. In: European Journal of International Law, 23(3), 2012, p. 722.

${ }^{33}$ Ibidem, p. 726.

${ }^{34}$ See: ZUFFI, Stefano. Artist: Van Gogh. Milano: Motta 24 ore Cultura, 2014.

${ }^{35}$ SAX, Playing Darts with a Rembrandt..., pp. 8-9.

${ }^{36}$ ZEIDLER, Ograniczenie prawa własności..., p. 544.
} 
it is an object of property of a given subject-falls within the category of the common good, or if even more directly it is a common good, then its free disposal turns out to be significantly limited. ${ }^{37}$ It all depends, then, on whether the work of art represents values which imply a public interest in its preservation, and this is so in the case of The Portrait of Dr. Gachet.

However, everything is complicated by the fact that the disposal of the painting was made in a testament, expressing the last will of Ryoei Saito. The millionaire, under his property rights, wanted Van Gogh's painting, generally perceived as a common good, to be burned along with his corpse. Upon his death, he can no longer change his mind and, in view of morality and customs, his will should be respected and fulfilled. However, this is in conflict with the public interest.

So we have a clear-cut conflict between liberal democratic principles and communitarian ideals. It should be emphasised that this dispute is not based on extremely opposing positions and an attempt to implement its concept, but has currently a discursive character, in the sense that none of the ideas and principles is absolute. And such a compromise would have to be made by the judge, weighing the values and principles, in search of a solution to our hard case-whether to allow the fulfilment of Ryoei Saito's last will or not.

\section{Conclusion}

The case of The Portrait of Dr. Gachet shows us that the issue of hard cases is still relevant, in particular in cultural heritage law. A characteristic feature of hard cases is the lack of one right answer and the necessity to constantly weigh the rules in order to give priority to one of them in a specific case. The decision will always depend on a specific factual state. We can also deal with hard cases by simply referring to the rules of prudence and so-called common sense. It seems that this could be applied in the case of The Portrait of Dr. Gachet, because the dispute between the interest of the individual, expressed in the ownership of the work of art and the possibility of its disposal, and the common interest, treating the painting as a common good, will never be unequivocally resolved.

\section{References}

ARONSON, Jeffrey K. and Ramachandran, Manoj (2006). The diagnosis of art: melancholy and the Portrait of Dr Gachet. In: Journal of the Royal Society of Medicine, 99(7), pp. 373-374.

CHILVERS, Ian and OSBORNE, Harold (2004). The Oxford Dictionary of Art. Oxford: Oxford University Press. ISBN 978-0198604761

DUSZA, Karl (1989). Max Weber's Conception of the State. In: International Journal of Politics, Culture, and Society, 3(1), pp. 71-105.

DWORKIN, Ronald (1975). Hard Cases. In: Harvard Law Review, 88(6), pp. 1057-1109.

DWORKIN, Ronald (1977). Taking Rights Seriously. Cambridge: Harvard University Press. ISBN 0-674-86710-6

FRANCIONI, Francesco (2012). Public and Private in the International Protection of Global Cultural Goods. In: European Journal of International Law, 23(3), pp. 719-730.

GILLMAN, Derek (2010). The Idea of Cultural Heritage. Cambridge-New York: Cambridge University Press. ISBN 9780521122573.

${ }^{37}$ Ibidem. 
K. Zeidler - A. Guss: The Protection of Cultural Heritage vs. the Right to Private Property...

GOMBRICH, Ernst Hans (2009). O sqtuce. Warsaw: Wydawnictwo Arkady. ISBN 9788375102161.

HART, Herbert (1994). Postscript. In: The Concept of Law, 2nd ed., BULLOCH Penelope A. and RAZ, Joseph (eds.) Oxford: Clarendon Press. ISBN 978-0198761228.

HAUPT, Simon (2007). Muzeum zaginionych dzieł. Historia kradzieży dziet sztuki. Warsaw: Wydawnictwo Arkady.

KLINE Linus W. and FRANCE, C. J. (1899). The Psychology of Ownership. In: The Pedagogical Seminary, 6(4), pp. 421-470.

KRAMER, Matthew H. (2004). Where Law and Morality Meet. Oxford: Oxford University Press. ISBN: 978-0199274192.

LEITER, Brian (2003). Beyond the Hart/Dworkin Debate: The Methodology Problem in Jurisprudence. In: The American Journal of Jurisprudence, 48(1), pp. 17-51.

LOCKE, John (1980). Second Treatise of Government. Indianapolis: Hackett Publishing Co., Inc. ISBN 978-0915144860.

LYONS, David (1984). Ethics and the Rule of Law. Cambridge: Cambridge University Press. ISBN 9780521277129.

MACK, Eric (2010). The natural right of property. In: Social Philosophy and Policy, 27(1), pp. 53-78.

NEFF, Stephen C. (ed.) (2013). Hugo Grotius on the Law of War and Peace. Cambridge: Cambridge University Press. ISBN 9781139031233.

SALTZMAN, Cynthia (1998). Portrait of Dr. Gachet: The Story of a van Gogh Masterpiece: Money, Politics, Collectors, Greed, and Loss. New York: Viking. ISBN 978-0140254877.

SAX, Joseph L. (2004). Playing Darts with a Rembrandt: Public and Private Rights in Cultural Treasures. Ann Arbor: The University of Michigan Press. ISBN 978-0-472-08784-6.

SCHWARTZ, Gary (1996). Ars Moriendi: The Morality of Art. In: Art in America, 1996(11), pp. $72-75$.

SHAPIRO, Scott J. (1997). The "Hart-Dworkin" Debate: A Short Guide for the Perplexed. In: Ronald Dworkin (ed.). RIPSTEIN, Arthur. Cambridge: Cambridge University Press. ISBN 9781139167109.

WALLACE, Robert (1969). The World of Van Gogh, New York: Time-Life Books. ISBN 0316510807.

ZAJADLO, Jerzy (2008). Co to są hard cases? In: Fascynujace ścieżki filozofii prawa, ZAJADLO, Jerzy (ed.). Warsaw: LexisNexis. ISBN 978-83-7334-869-1.

ZALEWSKI, Zbigniew (2003). Psychologia własności i prywatności. Warsaw: Wydawnictwo Żak. ISBN 8388149946.

ZEILDER, Kamil (2016). Ograniczenie prawa własności w świetle sporu liberalizmu z komunitaryzmem. In: Gdańskie Studia Prawnicze, 36, pp. 535-551.

ZEIDLER, Kamil (2016). Restitution of Cultural Property. Hard Case, Theory of Argumentation, Philosophy of Law. Gdańsk-Warsaw: Gdansk University Press. ISBN 978-83-7865-462-9.

ZEIDLER, Kamil (2018). Czy w prawie prywatnym występują trudne przypadki? In: Państwo $i$ Prawo, 9, pp. 69-77.

ZEIDLER, Kamil and LA_GIEWSKA, Magdalena (2020). Liberalism Versus Communitarianism in Cultural Heritage Law. In: International Journal for the Semiotics of Law - Revue internationale de Sémiotique juridique, 34(1), pp. 657-668.

ZUFFI, Stefano (2014). Artist: Van Gogh. Milano: Motta 24 ore Cultura. ISBN 978-8866482161. 